\title{
LIMMER, Josef, Konzilien und Synoden im spätantiken Gallien von 314 bis 696 nach Christi Geburt
}

Charles Mériaux

\section{OpenEdition}

\section{Journals}

Édition électronique

URL : http://journals.openedition.org/ifha/845

DOI : $10.4000 /$ ifha. 845

ISSN : 2198-8943

Éditeur

IFRA - Institut franco-allemand (sciences historiques et sociales)

Référence électronique

Charles Mériaux, «LIMMER, Josef, Konzilien und Synoden im spätantiken Gallien von 374 bis 696 nach Christi Geburt », Revue de l'IFHA [En ligne], Date de recension, mis en ligne le 01 janvier 2005, consulté le 22 septembre 2020. URL : http://journals.openedition.org/ifha/845 ; DOI : https://doi.org/10.4000/ ifha.845

Ce document a été généré automatiquement le 22 septembre 2020.

(C)IFHA 


\title{
LIMMER, Josef, Konzilien und Synoden im spätantiken Gallien von 314 bis 696 nach Christi Geburt
}

\author{
Charles Mériaux
}

1 L'épiscopat gaulois réuni en conciles a livré une abondante documentation normative entre le début du IVe s. et la fin de l'époque mérovingienne. Les actes de ces assemblées sont bien connus et aisément accessibles. Carl Joseph Hefele en a donné une longue analyse dans sa monumentale Conciliengeschichte (1855-1874), traduite en français et complétée par Henri Leclercq dans les premières décennies du XXe s. ; ces canons ont été réédités par Charles Munier et Carlo de Clercq dans le Corpus christianorum en 1963 ; Jean Gaudemet et Brigitte Basdevant en ont ensuite donné une traduction française pour la collection des Sources chrétiennes. Il convient enfin de citer les études fondamentales consacrées à l'ensemble de ces textes par Carlo de Clercq (1936) et Odette Pontal (1986). Depuis ces travaux, certains conciles ont fait l'objet de recherches plus approfondies concernant en particulier la tradition des canons ou encore leur intérêt pour l'histoire du droit dans l'Antiquité tardive et le très haut Moyen Âge. Ces recherches ponctuelles méritaient d'être rassemblées. Le titre de l'ouvrage de J.L. pouvait laisser espérer que l'auteur s'était engagé dans cette voie. Ce n'est pas le cas. Le premier volume (Teil 1 : Chronologische Darstellung) présente dans l'ordre chronologique les 79 assemblées qui se sont tenues entre le concile d'Arles (314) et le synode diocésain réuni par Tetricus d'Auxerre en 692/696. L'auteur détaille les circonstances dans lesquelles se tint chaque réunion, énumère les participants et propose à chaque fois une analyse très développée (mais non une authentique traduction) des canons promulgués. Ces notices n'ont guère d'intérêt : elles se contentent en effet de compiler ce que l'on pouvait déjà trouver dans les travaux cités plus haut. La bibliographie est mince. Les recherches récentes, parfois nombreuses, que tel ou tel concile a pu susciter ne sont pas signalées. Deux exemples : il n'est pas fait mention de l'article fondamental donné par Hanns Christoph Brennecke sur le faux concile de Cologne (346) dans la Zeitschrift für Kirchengeschichte (t. 90, 1979, p. 30-54) ou encore des actes du colloque organisé en mars 1998 à l'occasion du seizième 
centenaire du concile de Turin réuni à la demande de l'épiscopat gaulois (Massimo di Torino, Turin, 1999). Le second volume (Teil 2 : Zusammenschau wichtiger Themenkreise) développe les différents thèmes abordés dans ces canons qui, on le sait, procurent un vif éclairage sur le rôle de l'évêque, les rapports entre le roi et l'épiscopat, la discipline du clergé, le statut des monastères, l'organisation de la liturgie, etc. On déplorera une nouvelle fois l'absence totale de renvois aux travaux récents sur ces différents aspects. Le livre de Robert Godding sur les Prêtres en Gaule mérovingienne (Bruxelles, 2001) n'est même pas cité. Ce second volume paraît cependant propre à rendre quelques services, même si son utilisation ne se fera pas sans vérifications dans les indices des ouvrages plus anciens. Le lecteur ne doit donc pas être trompé, le livre de J.L. n'est pas la grande synthèse sur la législation religieuse des évêques gaulois qu'annonçait pourtant son titre.

Charles MERIAUX (Université Charles de Gaulle-Lille III) 